Яременко Н. В. кандидат філологічних наук, дочент Криворізький педагогічний інститут ДВНЗ «Криворізький начіональний університет»

\title{
ВЕРБАЛІЗАЦІЯ ФЕНОМЕНА СТРАХУ У ПРОЗІ О. П. ДОВЖЕНКА ПЕРІОДУ ВІЙНИ
}

У статті з'ясовано специифіку реалізації феномену страху в кіноповістях О.П.Довженка періоду війни. Значну увагу приділено засобам вираження иьього емочійного модусу на різних рівнях текстової організації прози мития.

Ключові слова: страх, вербалізачія емочї, психологізм, проза. 
В статье осмыслена специфика реализации феномена страха в киноповестях А.П.Довженко периода войны. Особенное внимание сосредоточено на способах выражения этого эмочионального модуса на разных уровнях текстовой организации прозы творияа.

Ключевые слова: страх, вербализаџия эмоции, психологизм, проза.

The article comprehended specificity of the phenomenon of fear in the A.P.Dovzhenko's movie-stories of the war. Particular attention is focused on ways to express this emotional modus on different levels of the text organization of the creator's prose.

Keywords: fear, verbalization of emotions, psychologism, prose.

Неможливо знайти людину, яка б ніколи не переживала відчуття страху. Попри це до сьогодні ні в літературознавстві, ні у психології, ні у психолінгвістиці не вироблено єдиної теорії досліджуваного феномена. Психологи стверджують, що саме страх у різних його проявах (страх за життя, своє чи близьких людей, страх перед невідомим, страх виділитися 3-поміж собі подібних тощо) є однією з домінантних емоцій людини. На думку Ю.В.Щербатих, страх - це внутрішній стан, обумовлений майбутньою реальною або ймовірною загрозою [Щербатых 2007:21]. Тобто, ця емоція виникає тоді, коли людина перебуває або вважає, що перебуває в ситуації, яку сприймає як потенційно небезпечну для іiі внутрішнього комфорту, соціального чи біологічного існування. Крім того, страх, як і будь-яка емоція, є складовою антропологічної культури людства в цілому та має специфічні для кожного окремого народу риси, обумовлені відмінними ментальними реакціями на події та різними для кожного етносу знаковими формами.

Одним із важливих напрямів розвитку сучасної філологічної науки є вивчення сутності проявів людського в людині, іiї природи, «дому буття» (за М.Хайдеггером), що уможливлює здійснення самопізнання, самоіндентифікації індивіда. Першочерговим у вивченні особистості є заглиблення в рефлексії оприявлені нею в межовій ситуації, зокрема під час війни як «крайньої межі, щзо ї̈ поставлено всякому людському існуванню» [СБФ 1978:300]. Війна ж як максимально інтенсивний стресогенний фактор генерує сильні 
негативно-емоційні поля, у межах яких повною мірою проявляються етнокультурні традиції учасників протистояння, їхній духовний потенціал, здатність долати страх.

Метою нашої статті стала потреба вивчити воєнну прозу О.Довженка в аспекті вербалізації феномену страху та оцінити трансформуючий потенціал цієї емоції з позицій літературознавства та психології.

Для багатьох письменників XX століття Друга світова війна стала не лише важливою темою творчості, а й своєрідним моментом істини. Про необхідність із максимальною пристрастю відтворити масштаби воєнного лиха як генератора такого деструктивного начала, як страх, і накреслити шляхи його подолання О.Довженко зазначав у одному із щоденникових записів: «Дійсність стала набагато страшнішою за всяку уяву. I ї так $і$ треба показати. Душа людська міряється повною мірою, та такою, про яку навіть $i$ не підозрював світ. Книги $і$ фільми про нашу правду, про наш народ мусять тріщати од жаху, страждань, гніву $і$ нечуваної сили людського духу» [Довженко 1994 :113].

Творчість О.Довженка воєнного періоду є знаковою і тому перманентно перебуває в полі зору дослідників-літературознавців протягом більш ніж півстоліття. Як справедливо вважає В.Хархун, «художня глибина написаного митием у роки війни увиразнює його лідерську позицію в контексті радянської літератури» [Хархун 2009:355]. Саме О.Довженко був одним із перших письменників, що показали і осмислили всю глибину горя, яке спіткало український народ під час війни. У своїх творах автор показав антигуманне єство будь-якого насилля. Як зауважує М.Наєнко, «найнезвичайнішою у Довженка постає війна як така: вона теж життя, але життя в найбезглуздішому вияві, бо апофеоз цього життя - убивання всього живого» [Наєнко 2000:270].

Слід відзначити, що соцреалістичний канон, у межах якого змушений був творити митець, вимагав реалізації чітко окресленого міфу війни як «визвольної», «правдивої», «священної». На пое- 
тикальному рівні це виражається в побудові чіткої опозиції «герой ворог». «Пафосна двополюсність мотивована як ідеологічною дочільністю, так і щиролюдськими вболіванням Довженка - радянського патріота, який активує увесь арсенал романтичної поетики для увиразнення офіційного тексту війни» [Соколов 1998:367]. Своєрідним маркером тут стає відчуття страху і спроможність його подолання, приборкання.

У кіноповісті «Україна в огні» спостерігаються найрізноманітніші ознаки естетичного сприйняття й відображення реальної дійсності від гармонійного, піднесено героїчного до драматичного напруження та навіть трагічного, катастрофічного передчуття. На нашу думку, це зумовлено як життєвим матеріалом, що ліг в основу твору, так і ідейно-художнім задумом, надзавданням, що визначає індивідуальний код і творчий метод письменника. Усі акцентно-зображальні засоби підпорядковані провідній ідеї - відобразити трагедію України, створити образ народу-воїна. Письменником відображено специфічний характер життя людини під час війни. Постійна загроза існуванню провокує генерацію страху в різних його проявах: тривога як оцінна стадія - острах як стан усвідомлення небезпеки - власне страх як стан повної дезорганізації психологічної структури особистості - жах як стан, що уможливлює деградацію особистості, руйнацію організму.

Уже на початку твору автором спостережено проблему роздрібнення етносу, наявність протистояння у межах однієї спільноти: «Ревли по шляхах грузовики без кіния й краю, везли втікачів. У важкому смутку оглядались стомлені втікачі назад. Усе, щзо не їхало з ними, починало здаватись їм ворожим, і страх заповнював їхні душі, і приховане зло, і мовчазний відчай» [Довженко 1994:15]. Метафоричне сполучення «страх заповнював їхні душі» передає початковий модус експресивної реалізації емоції страху, стан, що проявляється на рівні між тривогою й острахом. Психологічний стан «втікачів» увиразнено митцем через застосування епітетів «важкий смуток», «приховане зло», «мовчазний відчай». Таким чином 
виписано захисний механізм, який включається задля протидії страхові. У психології цей механізм називається проекцією: людина приписує свої власні табуйовані дії (паніка, зрада, втеча від ворога) комусь іншому, чим деформує реальність [Ильин 2001:112].

У кіноповісті «Україна в огні» звертає на себе увагу своєрідність відтворення вищих проявів людського духу, які в екстремальних умовах стають масовими явищами: «Смерть не поскупилася на них, не пожаліла на них ні гриму, ні фарб, ні роз'ятрених ран, ні жорстоких нелюдських калічтвв <...> Ніхто вже не впізнав би їх ні батьки, ні матері, ані дружини. Та й самі вони в останній час уже не взнавали один одного, так змінили їх пристрасті смертельного бою <..> Все віддали. Все до останньої нитки. Поквиталися з життям, з війною, з ворогами на всю силу. Не мудрували, не ховалися по резервах і тилах, не обростали родччами на простих своїх артилерійських постах. Не видушували з простих своїх талантів великої користі, нехтували талантом, не любили виставляти на показ ні в иілому вигляді, ні в пораненому, ні в яких доблестях» [Довженко 1994:97]. Повтор заперечних часток “не”, “ні” підсилюється повтором прийменника “в”, займенників “на них”, “все”, що мають у тексті акцентно-виразне значення. Письменник представляє у творі проблему “людина і війна” у соціальному i моральному плані. Якості воїнів проявляються в гіпертрофованому вигляді, оскільки їхні вчинки оцінюються по іншій моральній шкалі, окресленій суворістю буття. У наведених рядках лексичні повтори мають акцентно-виразне значення. Вони ритмізують фразу, створюють драматичне нагнітання, підкреслюють антигуманний характер війни як соціальної катастрофи і підносять високу моральність, благородство тих, хто стояв на ії шляху, щоб зупинити. Змальовуючи страшну картину знищеної ворогом батареї Запорожця, письменник у романтичному ключі гіперболізує зображуване. При цьому повтор заперечних часток дозволяє автору увиразнити емоційний план оповіді, розкрити тему вічності героїчного в людині. 
Апокаліптична картина страхіть бойовища, увиразнює психологічні портрети персонажів, створює випукле, рельєфне тло: «Літали зграї переляканих, знавіснілих птищь над боєм. У повітряних хвилях, як у тайфуні, їх кидало від вибухів з боку в бік, вперед назад, вперед - назад! Вони падали від грізних ударів на землю, иукаючи захисту від чужих і страшних людей. Лисиці дрижали в смердючих лисичих норах. Вовки в кущах, наївшись людського м'яса, припадали черевами до землі і волочились, гидячи ї̈ в відчайдушному проклятому вовчому переляку. Від жаху у них віднялися ноги $і$ шлунки $i$ закарлючились хвости під животами. Вони валялись по кущуах, як дохлі, і повзали, не сміючи навіть вити, і клацали зубами. Вовчиці плакали. Такий страшний був світ у бою. Одна лише людина могла витерпіти бій» [Довженко 1994:98]. Через повтор епітетів «перелякані птиці», «вовчий переляк», «страшні люди», «страшний світ» митець відтворює атмосферу жаху, який вселяє війна навколишньому.

Про необхідність з максимальною пристрастю відтворити силу воєнного лиха О.Довженко зазначав у одному з щоденникових записів: «Дійсність стала набагато страшнішою за всяку уяву. I ї̈ так і треба показати. Душа людська міряється повною мірою, та такою, про яку навіть і не підозрював світ. Книги і фiльми про нашу правду, про наш народ мусять тріщати од жаху, страждань, гніву і нечуваної сили людського духу» [Довженко 1994:113]. Демонстративне протистояння сраху зумовлене романтичною тенденційністю зображення людини на війні і війни як планетарної катастрофи.

Своєрідним комплексом поведінкових проявів страху є епізод страти старого Демида. Тут страх виступає своєрідним соціальним оцінним маркером. В залежності від духовного рівня персонажа відтворюється і його здатність протистояти цьому почуттю. Реакція ворога: «Цю землю можна їсти! На! Їж! < ...> O, страшна земля. - задумавсь раптом старий Крауз. - О!. Ні!. Так не підкорятися $і$ так умирати, як умирають українці, можуть лише 
люди високої марки. Коли я дивлюсь на їхню смерть, я завжди тремчу од жаху» [Довженко 1994:112]. У розмові батька і сина фон Краузів слово-образ «жменя землі» виступає як матеріальна сутність, ознака добробуту й багатства, бо це не просто земля, а знамениті на весь світ українські чорноземи, що у своїх надрах народжують живе золото - пшеницю, а потім, переосмислюючись, набуває значення джерела духовної міцності й сили народу. У вуста ворога автор вкладає гірку й болючу правду про причини деградації суспільства, виховуваного на негативних лозунгах і непошані до Бога: «Вони вже двадиять п'ять літ живуть негативними лозунгами відкидання бога, власності, сім $\dddot{i}$, дружби! <..> Тому серед них так багато зрадників» [Довженко 1994:27-28].

Ця думка знаходить продовження й у змалюванні сцени страти поліцая Івана Гаркавенка партизанами. При цьому О.Довженко знову звертається до образу «жменя землі»: «Коли перед ним звелися дула рушниць, він упав перед ними на коліна $i$, схопивши жменю землі, заплакав: «- Клянуся святою рідною нашою землею! От щуоб я подавився нею, гляньте!» - він почав їсти землю, обливаючись сльозами» [Довженко 1994:61]. У цьому контексті «жменя землі», рідної землі, сприймається читачем як мірило чесності перед собою і співвітчизниками, остання інстанція, до якої може апелювати людина, благаючи про порятунок, навіть така нікчемна «загублена душа», як поліцай Гаркавенко. О.Довженко, осмислюючи проблему відступництва, доводив, що перш ніж засуджувати, необхідно виявити й зрозуміти причини цього явища. На думку письменника, людина не може бути злочинною за своєю природою, такою їі роблять обставини й соціальна дійсність. «Де ж рождатися, де плодитися дезертирам, як не у нас? - наголошує письменник у щоденнику, - Де рости слабодухим і запроданцям. Як не у нас? Не вина це дезертирів, а горе. Не судить їх треба, а просить пробачення і плакати за погане виховання, за духовне каліцтво у великий час < ..> Юнаки мої сліпії, горе мені з вами» [Довженко 1994:135]. Рядки з твору і рядки щоденника співзвучні, 
вони є своєрідним звинуваченням тоталітарному режиму, його політиці.

Останні хвилини діда Демида змальовано в стилі «макабричної поезії»: «Світ здурів, то й бджоли подуріли. Почали всяке г. кусать, - сказав Демид. - А думаю я, що погані ваші діла, раз уже ви боїтесь таких, як я» [Довженко 1994:119]. Герой сміливо дивиться в очі смерті, проявляючи дивовижну хоробрість. Цікавим, на нашу думку, є припущення Карла фон Клаузевиця, що мужність у жодному разі не є проявом розуму, а являє собою те ж почуття, що і страх; останній направлений на фізичне самозбереження, а мужність - на моральне [Довженко 1994:127] Таким чином старий Демид долає страх смерті, абстрагується від нього завдяки вибудуваним чітким духовним пріоритетам, прищепленим 3 дитинства почуттям гідності, честі, жертовності. Цілком природною $\epsilon$ i психологічна реакція фон Краузів на таку провокацію: «Це страшно, - прошептав Людвіг, хворобливо всміхаючись» [Довженко 1994:119]. Вони потерпають від жаху, бо структура мотивації дій загарбників не має морального стрижня, вона хистка й непевна.

Такою ж нестабільною є й позиція дезертирів. Сини Хутірних, Гаркавенків, Товчеників, деморалізовані, без усвідомлення родової честі, без взаємної довіри, спільної мети скеровують свої дії лише інстинктом самозбереження. Психологічний стан, скажімо, Павла Хутірного засвідчує високий ступінь страху, від якого він потерпає: «Oт n'ю й не п'янію. Закушую і не маю смаку. Все, як трава. Все однакове. Все!» [Довженко 1994:125]. Такий стан показує, що персонаж перебуває за межами психічних можливостей, i, як це не парадоксально, каталізатором його життєвих сил на цьому етапі є тваринний страх. Одним із небагатьох аргументів, що їх наводить дезертир на своє виправдання є наступні: «Тепер бога нема!» та «Мені приказано. Що я буду робить?!» Справді, інстинкт самозбереження універсальний і детермінований біологічною природою людини, однак механізми захисту індивідуума в критичній ситуації повною мірою залежать від соціокультурних параметрів 
особистості, що визначають їі виховання, цінності, установки, норми поведінки. Як зазначено В.Соколовим, «страх європейияатеїста, християнина, мусульманина, буддиста і т.д. - ие різні страхи. I рішення ними в схожих умовах приймаються різні, навіть протилежні» [Соколов 1998 :108]. Справді, батькові переконання, сформовані на основі християнської етики й національного патріотизму, на підвалинах родової честі й гідності не можна порівняти за силою впливу 3 ідеологічними установками, що їх нав'язували поколінню народженому в 20 -х роках XX століття. I тому з таким обуренням звучать слова Купріяна Хутірного: «Коли ж ие було видно, щоб у Хуторних був страх смерті? Щоб Хуторні боялися крові?» [Довженко 1994:39].

Прагнення Олесі Запорожець до збереження чистоти роду спонукало дівчину до незвичайного вчинку, який був порушенням народних звичаїв, які унеможливлювали позашлюбні зв'язки між дівчиною і юнаком: «I рішилася вона на крок нечуваний, небачений ні в ї̈ селі ніколи, ні в усім ї̈ народі. На вчинок незвичайний. На вчинок грізний, щзо підказав їй грізний, надзвичайний час. Що кинуло ї̈ на цей учинок? Що наштовхнуло? Глибина інстинкту роду, підсвідома мудрість, що з'являються на допомогу людині в грізні часи» [Довженко 1994:20]. Про цей вчинок дівчини О.Довженко говорить небуденно, піднесено, подаючи образ дівчини Олесі, що уособлює в собі узагальнений образ “української дівчини-жінки”, берегині роду: «Неначе зійшлися століття простої народної любові, щуо сіє дітей на намій родючій землі. Зійшлися століття горючих прощань української дівчини-жінки, оспіваної в журних nicнях народних» [Довженко 1994:23]. Страх, який переживає персонаж в цій ситуації, має соціальну природу: «Я дівчина. Я знаю, прийдуть німці завтра чи післязавтра, замучать мене, поругаються наді мною. А я так цього боюсь, прошу тебе, нехай ти. переночуй зі мною. - При останніх словах голос Олесі затремтів і неначе погас» [Довженко 1994:21]. 3 одного боку, це тривога, острах засудження найближчим оточенням, з іншого, на порушення поведі- 
нкового табу дівчину штовхає теж страх - страх віддати ворогові найцінніше з точки зору народної моралі - свою цноту. Герої поєднуються, сповнені високої мети продовжити рід, зберегти його, всупереч усьому: «Василь чув як стугоніло його серие.

- Як у мене б'сться серие...

- I у мене, - сказала тихо Олеся» [Довженко 1994:21]. Ці ж слова зринають у маренні пораненого Василя Кравчини, виступаючи своєрідним емоційним резонансом:

«-Яку мене б'ється серие... Як у мене б'ється серие... Олесю! Як у мене б’ється серие! Ай!...- стогнав у нестямі Василь» [Довженко 1994:64]. Повтор на синтаксичному рівні дозволяє письменникові передати драматичну напруженість моменту, показати урочистість і емоційну наснаженість ситуації. Саме жінка $з$ iï відкритим гарячим серцем, здатністю на глибокі почуття й самопожертву постає рятівним колом у найстрашніші хвилини буття чоловіка-воїна. У екстремальній ситуації, перебуваючи між життям і смертю, герой подумково звертається до Олесі, чий образ проніс він «через усі бої, через усі вогні», і яка не була для нього «чужою, невідомою, випадковою», глибоко запала в серце. У наступному епізоді митець через синтаксичний повтор створює ефект безперервності дії і наголошує на нерозривному підсвідомому зв'язку героїв: «Його поклали на стіл. Він чув, як стогнали навколо поранені і кричали б'ючись на страшних своїх хірургічних столах.

- Як у мене б’ється серце? Олесю... Як у мене б'ється серце... Олесю, ай-ай-ай! Як у мене б’ється серце - кричав він у нестямі» [Довженко 1994:65]. Автор наголошує, що неодноразово йдучи тяжкими дорогами війни, його герой знаходився між життям і смертю, але навіть у маренні він думкою летів до найдорожчої йому людини, яка змусила його серце битись по-новому, пробудила волю до життя.

Варто відзначити, що в кіноповісті традиційно для соцреалістичного канону сконструйовано образ ворога. Найповніше він постає в образах батька й сина фон Краузів. Для цих персонажів 
характерними є тверде переконання у своїй правоті, агресивність, жорстокість, підступність і разом із тим патологічне боягузтво і дивна сентиментальність. Так, страх смерті реалізується у цих персонажів як почуття, що повністю дестабілізують психіку, навіть приводять до деградації: «Фон Крауз схопився з ліжка і затремтів од жаху. Ховатися! Куди? Заходив будинок од вибухів бомб. У місто вривавсь Запорожець <..> Від сильного удару фон Крауз трохи очумався. 3 почуттям великого страху він відчув раптом, що Запорожців ляпас вибив 3 нього щось найважливіше, що становило головну його суть < ..> Фон Крауз здригнувся. < ..> Запорожці... Як він ненавидів їх за розбиті свої мрії! Але ненависть уже облишила його, огидний страх заморожував дихання» [Довженко 1994:99]. Абстрактно-теоретичний образ ворога, який нав'язувала митцеві соцреалістична традиція, набуває тут психологічної випуклості, особистісно-емоційної виразності.

Наступний епізод, що ми його наводимо, оприявлює елемент емоційного відторгнення, особистісного неприйняття автором образів загарбників: «Вороги йшли напівголі, брудні, з волохатими грудьми й животами і являли собою картину жалюгідну й мерзотну, мов божевільний дім, щуо вирвався на волю. Вони реготали, свистіли й вили, пританщьовуючи і тільки несамовиті од жаху їхні очі видавали тупе страждання. Вони були неначе вже не люди, а лихий сон недужої людини» [Довженко 1994:18]. Війна у психологічному плані явно відноситься до категорії «межової ситуації», а значить людина у війні постійно перебуває в стані максимальної небезпеки, невизначеності, непередбачуваності загрози самому життю. У найкритичніші моменти втрачається здатність контролювати свідомість, а жах провокує неадекватні реакції, які автор окреслює в тексті прямим називанням: «вони реготали, свистіли й вили, пританцьовуючи», «їхні очі видавали тупе страждання», «мов божевільний дім». Митець показує, як афект повністю паралізує свідомість і вимикає здатність людини до раціонального мислення. Страх стає мукою, соромом, болем душі й тіла. 
У певному сенсі ситуація під час бойовища не залежить від волі й розуму людини, провокуючи цим схильність до пошуку особистістю духовної опори. Традиційно такою опорою була віра й віковічні підвалини народної моралі: «Поможи вам господи $i$ пречиста мати божа, - сказала стара Бесарабиха. - Прощати треба один одному більше та співчувати, - тихо звернулась вона до Сіроштана... Сіроштан мовчав. Він стояв перед старою матіp'ю, на яку впало величезне горе, беззбройний і маленький. На нього дивилися десятки очей. Для врятування репутації загартованого рубаки йому хотілося сказати щось грубе або смішне, та він не знаходив у собі ичих слів. Ним оволоділо раптом дивне збентеження» [Довженко 1994:89]. Згорьована, змучена літня жінка вивищується над ситуацією і дає ідеальний рецепт подолання біди. Адже війна лише проявляє зло, в основі якого лежить духовне насилля. I страх, і жорстокість, і слабкість, на їі думку, можна подолати через прощення. Людина не повинна віддавати на поталу свою душу й перетворюватися на механічну зброю для реалізації цілей держави. Власне, ця думка є наскрізною у творі.

Таким чином, нами 3'ясовано, що у воєнній прозі О.Довженка зокрема в кіноповісті «Україна в огні» завдяки актуалізації значного масиву поетикальних засобів відтворено особливості переживання індивідуумом страху як досить складного, індивідуально забарвленого почуття. Автором доведено, що у хвилини смертельної небезпеки в людині пробуджується інстинкт самозбереження, викликаючи природне почуття страху, однак за умови наявності в їі свідомості міцного стрижня, сформованого на основі духовних пріоритетів, створюються підстави для подолання, приборкання цього почуття.

\section{БІБЛІОГРАФІЯ}

Довженко 1994 - Довженко О.П. Кіноповісті: Щоденник / Олександр Довженко. К. : Веселка, 1994. - 432 с.

Ильин 2001 - Ильин Е. П. Эмоции и чувства / Е. П. Ильин. - СПб. : Питер, 2001. - 752 с. Клаузевиц К. О войне / Карл фон Клаузевиц. Режим доступа:

[http://militera.lib.ru/science/clausewitz/index.html] 
Наєнко 2000 - Наєнко М. Романтичний епос. Ефект романтизму і українська література /М. Наєнко - К. : Просвіта, 2000. - 379 с.

Соколов 1998 - Соколов А. К. Социальная история России новейшего времени: проблемы методологии и источниковедения / А.К.Соколов // Теоретические проблемы исторических исследований. - Вып. 1. - М., 1998. - С. 105-108.

Хархун 2009 - Хархун В. Соцреалістичний канон в українській літературі: генеза, розвиток, модифікації: монографія / Валентина Хархун. - Ніжин: ТОВ «Гідромакс», 2009. - 508c.

Щербатых 2007 - Щербатых Ю.В.Психология страха/ Ю. Щербатых. - М. : Эксмо, 2007. -512 c.

Стаття надійшла 1 грудня 2013 р. 